\title{
Organic carbon enhances dark survival of the cyanobacterium Geitlerinema sp. isolated from black band disease of corals
}

\author{
L.L. Richardson \& D.N. Ragoonath \\ Department of Biological Sciences, Florida International University, Miami, Florida, 33199, USA. Tel.: 305 348-1988, \\ Fax: 305 348-1986; Laurie.Richardson@fiu.edu
}

Received 15-VI-2007. C Corrected 01-XI-2007. Accepted 13-II-2008.

\begin{abstract}
Black band disease (BBD) of corals is characterized as a pathogenic, horizontally migrating microbial mat that is dominated by gliding, filamentous cyanobacteria. These cyanobacteria are important in BBD etiology in that they form the dense matrix of the band and are the source of a cyanotoxin that contributes to BBD pathogenesis. The BBD environment is chemically dynamic, fluctuating between oxic and anoxic conditions, and often contains high levels of sulfide. Additionally, it is nutrient and organic carbon rich due to the presence of actively lysing coral tissue and coral mucus. BBD cyanobacteria are physiologically adapted to the BBD environment in both light and darkness. Previous work has shown that BBD cyanobacteria can perform sulfide-insensitive oxygenic photosynthesis during the day. We report here the results of laboratory studies of a culture of the BBD cyanobacterium Geitlerinema sp. aimed at investigating metabolism during darkness. This isolate exhibited enhancement of survival supported by exogenous organic carbon sources (both sugars and amino acids) during darkness under both aerobic and anaerobic conditions, with the greatest effect seen under anaerobic conditions. Thus this BBD cyanobacterium is physiologically adapted to the anaerobic, organic rich environment of BBD at night as well as the sulfide-rich, illuminated band environment during the day. Rev. Biol. Trop. 56 (Suppl. 1): 119-126. Epub 2008 May 30.
\end{abstract}

Key words: Cyanobacteria, fermentation, Geitlerinema sp., black band disease, microbial mats.

Black band disease (BBD) of corals affects 64 species of scleractinian and six species of gorgonian corals and is found on coral reefs worldwide (Sutherland et al. 2004). It exists as a migrating dark band, several mms to $\mathrm{cms}$ wide, that progressively lyses coral tissue, leaving behind exposed coral skeleton (Figure 1). Migration rates are typically an average of $3 \mathrm{~mm} /$ day, although some bands have been reported to migrate up to $1 \mathrm{~cm} /$ day (Rützler et al. 1983). The disease is particularly detrimental to its scleractinian, reef building hosts because most of these species grow on the order of $1 \mathrm{~cm}$ in diameter per year (Hudson 1981). As a result of the difference in disease progression vs. coral growth rates BBD often causes coral colony death by massive tissue lysis (Antonius 1981, Rützler and Santavy
1983, Kuta and Richardson 1996, Bruckner and Bruckner 1997).

BBD has many characteristics in common with cyanobacterial dominated microbial mats found in a variety of illuminated, sulfiderich environments (Carlton and Richardson 1995). Such environments include hot spring outflows and hypersaline ponds and lakes (Stal 1995). Like many microbial mats, BBD exhibits an active sulfur cycle (Jørgensen et al. 1979, Carlton and Richardson 1995). Previous studies using oxygen and sulfide sensitive microelectrodes (Carlton and Richardson 1995, Richardson et al. 2001) have shown that BBD contains vertical, opposing gradients of sulfide and oxygen that are identical to those found in microbial mats. Additionally BBD microorganisms, most notably the cyanobacteria 


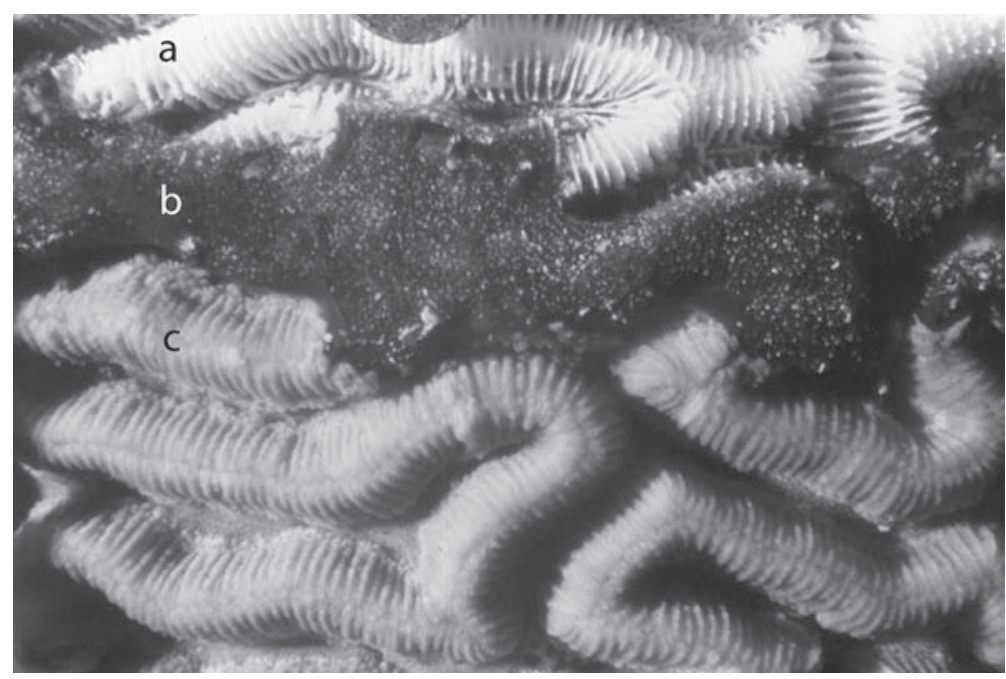

Fig. 1. Black band disease on Diploria strigosa $. \mathrm{a}=$ freshly exposed coral skeleton, $\mathrm{b}=$ black band disease, $\mathrm{c}=$ apparently healthy coral tissue.

and gliding sulfide-oxidizing bacteria, carry out vertical migrations within the BBD mat (Richardson 1996, Viehman and Richardson 2002), again similar to those found in other microbial mats (Castenholz 1982, Jørgensen 1982, Richardson and Castenholz, 1987a, Castenholz et al. 1991, Garcia-Pichel et al. 1994). These vertical migrations result in exposure of the migrating organisms to microenvironments of dramatically changing conditions ranging from fully oxic to anoxic and from sulfide-free to sulfide-rich, with accompanying fluctuations in $\mathrm{pH}$ and Eh values. Studies have revealed that the physiology of microbial mat and BBD microorganisms are complex and dynamic, and are directly controlled by changes in chemical and light parameters (Jørgensen et al. 1979, 1986, Jørgensen 1982, Jørgensen and Revsbech 1983, Castenholz and Utkilen 1984, Richardson and Castenholz 1987a,b, GarciaPichel and Castenholz 1990, Castenholz et al. 1991, Richardson and Kuta 2003). For example, mat cyanobacteria have been shown to switch between oxygenic and anoxygenic photosynthesis (Jørgensen et al. 1986) and between aerobic respiration and fermentation (Richardson and Castenholz 1987b) based on the physical environment at any given time.
In addition to exhibiting a dynamic oxic/ anoxic environment, BBD is nutrient and organic carbon rich due to lysing coral tissue, with the ongoing tissue lysis providing a continual source of organic carbon to the BBD community as it migrates across its host coral. Organic carbon compounds are abundant in coraI mucus as well, and include glycoproteins, lipids, and the saccharides fucose, arabinose, galactose, ribose, mannose and glucose (Ducklow and Mitchell 1979, Coffroth 1990). The ability to utilize these organic carbon sources would be physiologically beneficial to BBD microorganisms.

We have been following several lines of research to define the physiological and etiological roles of cyanobacteria in black band disease. To date, physiological studies of BBD cyanobacterial isolates of two genera (Geitlerinema and Leptolyngbya) have shown that they can conduct oxygenic photosynthesis in the presence of sulfide (Richardson and Kuta 2003; Myers et al. 2007), a rare capability (Cohen et al. 1986) that would allow survival in the sulfide-rich band environment. Additionally we have shown that several isolates of these two genera from BBD produce the cyanotoxin microcystin (Richardson et al. 
2007) which contributes to BBD pathogenicity (unpublished). Furthermore, we have previously reported that cultured BBD Geitlerinema and freshly collected samples of the entire BBD mat cannot fix dinitrogen, thus would be dependent on fixed nitrogen from the environment, including lysing coral tissue (Richardson and Kuta 2003). We present here new results further defining the physiology of the BBD cyanobacterium Geitlerinema, specifically the ability to use organic carbon to enhance survival during darkness.

\section{MATERIALS AND METHODS}

Culture isolation and maintenance: The Geitlerinema culture used in this study (accession no. AF474001 in GenBank, Ragoonath 2005) was isolated from BBD on a colony of Montastraea annularis at Algae Reef in the Florida Keys in 1991. It is maintained photoautotrophically in algal mineral media (ASN III) buffered with EPPS (N- (2-hydroxyethyl) piperazine-N-3-propane sulfonic acid) at 1.2 $\mathrm{g} / \mathrm{l}$, with $\mathrm{pH}$ adjusted to 8.1. Stock cultures are grown in $125 \mathrm{ml}$ Erlenmeyer flasks at $30^{\circ} \mathrm{C}$ on a 12:12 light/dark cycle, with low light levels (30 $\mu$ Ein $\mathrm{m}^{2} \cdot \mathrm{s}^{1}$ ) of cool white fluorescent light.

Survival experiments: Survival under dark and light aerobic and anaerobic conditions was investigated in the presence of 18 different organic carbon sources. These were arabinose, arginine, asparagine, citrate, fructose, fucose, galactose, glucose, glutamic acid, histidine, lactose, lysine, maltose, mannitol, mannose, ribose, sucrose, and valine. Aerobic experiments were conducted using test tubes with sterile cotton plugs while anaerobic experiments used Hungate tubes in which the media were first heated, boiled, and cooled under a stream of $100 \%$ reagent grade $\mathrm{N}_{2}$ gas. Tubes for dark incubations were double wrapped in aluminum foil. Light conditions were the same as those for culture maintenance, i.e. $30 \mu$ Ein $\mathrm{m}^{2} \cdot \mathrm{s}^{1}$ coolwhite fluorescent light on a 12:12 light/dark cycle. Stock organic carbon source solutions were prepared to a concentration of

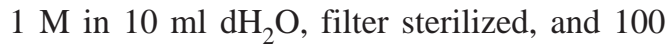
$\mu \mathrm{l}$ added to $10 \mathrm{ml}$ of ASN III media in each experimental test tube for a final concentration of $10 \mathrm{mM}$. Carbon sources were selected based on those reported to be present in coral surface mucopolysaccharide (Ducklow and Mitchell 1979, Coffroth 1990). All experiments were carried out in triplicate in a temperature-controlled incubator at $30^{\circ} \mathrm{C}$. Dark and light controls consisted of cultures with no exogenous organic carbon source provided. Each experiment was repeated three times and was carried out for a period of 20 days.

Cell death was used to document (absence of) survival. Cell death was determined by observation of the release of the red watersoluble pigment phycoerythrin to the surrounding medium as a result of filament lysis. Additionally, dead cells appeared green due to the maintenance of membrane-bound chlorophyll $a$ along with the loss of phycoerythrin. Cell survival was confirmed by microscopic observation of intact, motile filaments. Growth during the survival period was not quantifiable because heterotrophic bacteria living in close association with the polysaccharide sheath could not be removed from the culture.

Statistical analysis: All experiments were run in triplicate. The Shapiro-Wilk test was used to test for normality. A one-way ANOVA was performed on pooled carbon sources as well as Tukey-HSD Post-Hoc test for comparison of means.

\section{RESULTS}

Survival with exogenous organic carbon: The addition of organic carbon enhanced the period of survival of BBD Geitlerinema under both dark aerobic and dark anaerobic conditions. Under light aerobic (control) conditions there was survival in the presence of all organic carbon sources for the entire length of the experiment (20 days) with the exception of arabinose, in which cultures survived an average of 19.9 $( \pm 0.1)$ days (Figure 2a). Cultures incubated in dark aerobic conditions did not survive as long 

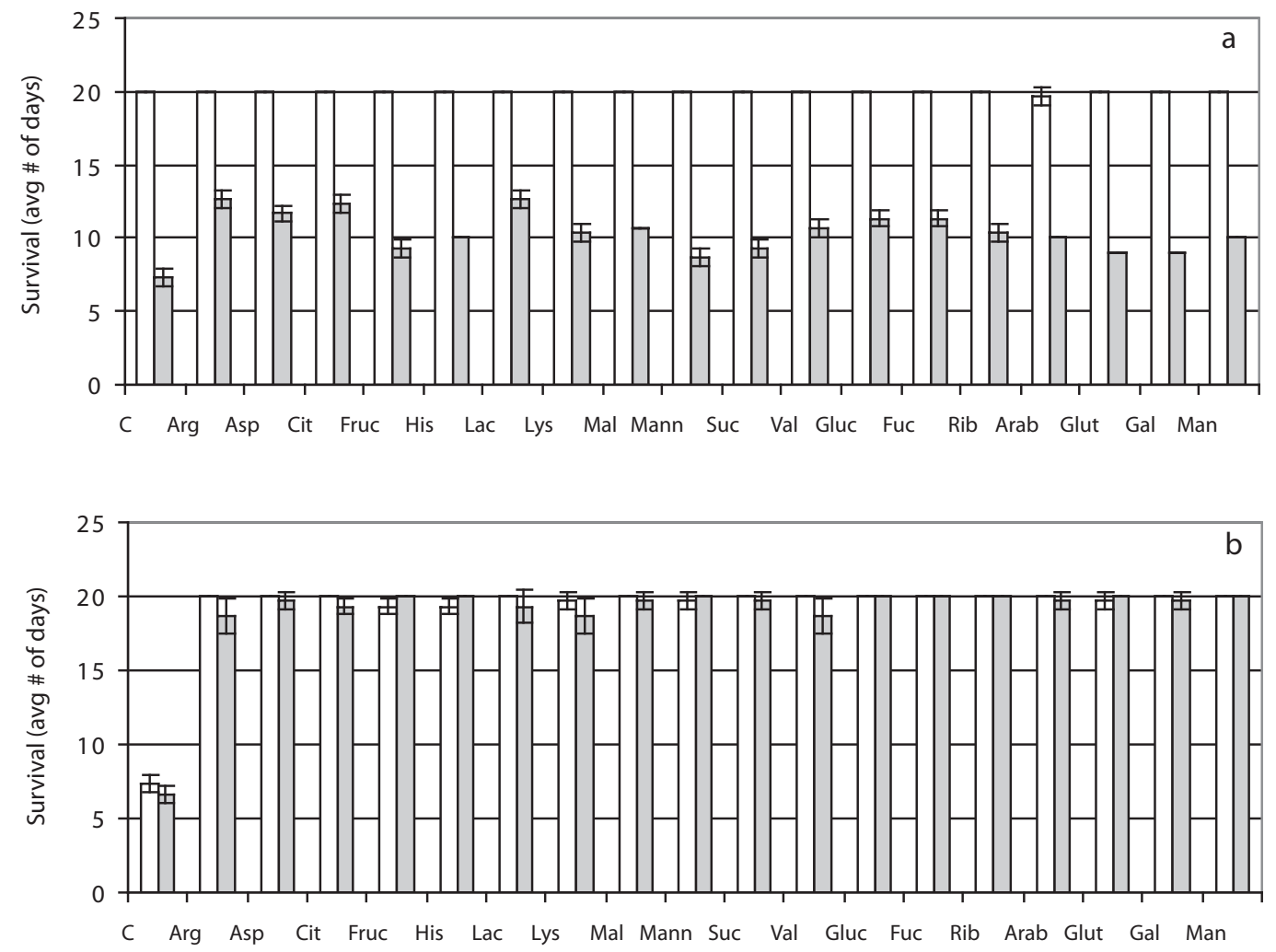

Fig. 2. Survival in light and dark aerobic (a) and anaerobic (b) conditions. Survival was monitored over a 20-day period. White bars represent survival in light conditions, shaded bars in dark conditions. $\mathrm{C}=$ control (no organic carbon); Arg = arginine; Asp = asparagine; Cit = citric acid; Fruc = fructose; His = histidine; Lac = lactose; Lys = lysine; Mal = maltose; Mann = mannitol; Suc = sucrose; Val = valine; Gluc = glucose $;$ Fuc $=$ fucose $;$ Rib = ribose; Arab $=$ arabinose; Glut $=$ glutamic acid; Gal = galactose; Man = mannose. Error bars indicate standard deviation.

as the controls. The greatest survival in dark aerobic conditions was supported by arginine and lactose, with average survival values of 12.7 days ( \pm 0.6 ) and 12.6 days ( \pm 0.5 ), respectively (Figure 2a). When exogenous organic carbon sources were excluded the cultures in dark aerobic conditions survived on endogenous carbon for 7.3 days $( \pm 0.5)$.

Survival under light vs. dark anaerobic (100\% $\mathrm{N}_{2}$ gas phase) conditions was not significantly different (Figure 2b). All cultures survived for an average of $19.3( \pm 0.1)$ days and $19.0( \pm 0.3)$ days, respectively. In both light and dark anaerobic conditions when organic carbon sources were excluded, cultures survived for no more than one week.
In the presence of exogenous organic carbon dark, anaerobic survival was significantly different (greater) than survival under dark, aerobic conditions (Tukey HSD Post-Hoc test, $\left.r^{2}=0.99\right)$.

\section{DISCUSSION}

Dark metabolism of cyanobactera: As discussed in a review by Stal and Moezelaar (1997) very little work has been carried out on cyanobacterial metabolism under anaerobic conditions and darkness. This is because all cyanobacteria generate oxygen during their preferred mode of metabolism, oxygenic photoautotrophy, and thus are often found in 
aerobic environments. Under dark aerobic conditions it is well known that all cyanobacteria can carry out aerobic respiration of glycogen (produced during photosynthesis), which is degraded via the oxidative pentose phosphate pathway (Matthijs \& Lubberding 1988). However, as pointed out in Stal and Moezelaar (1997), there are a variety of natural environments in which cyanobacteria experience prolonged periods of anoxia and darkness. These include anoxic hypolimnia of lakes and ponds, microbial mats, sediments of lakes and estuaries, surface water blooms, and in symbiotic associations with higher plants. It has been demonstrated repeatedly in laboratory experiments that cyanobacteria isolated from these environments are capable of fermentation of stored glycogen when exposed to darkness and anoxia (reviewed in Stal and Moezelaar 1997). Despite this widespread physiologic capability studies have found that only a very few cyanobacteria can make use of exogenous (as opposed to endogenous) organic carbon to support the ability to ferment. These include members of the genera Nostoc, Oscillatoria (with the relevant species reclassified as belonging to Geitlerinema), and Microcystis, as well as symbiotic species (Stal and Moezelaar 1997).

\section{Enhanced survival of BBD Geitlerinema} during darkness: Black band disease represents another example of a natural environment in which cyanobacteria experience prolonged periods of anoxia and darkness. Microelectrode studies of intact black band incubated in darkness revealed that the entire band becomes anoxic and sulfide rich, and that at times the oxygen/sulfide interface extends above the band into the water column (Richardson et al. 2001). Thus BBD cyanobacteria are exposed to an anaerobic (and reducing), organic-rich environment every night.

Our results reported here show that the BBD cyanobacterium Geitlerinema can use a variety of amino acids, sugars, and other organic carbon compounds to enhance survival in the dark under anaerobic (as well as aerobic) conditions. Under dark anaerobic conditions this cyanobacterium survived an average of 19 days with exposure to exogenous organic carbon, as opposed to a maximum of 12 days under aerobic conditions and seven days with no added carbon source.

Ecological significance of BBD cyanobacterial physiology in darkness: The observation that exogenous organic carbon enhances survival under both aerobic and anaerobic dark conditions, and that the most pronounced enhancement occurred in dark anaerobic conditions, is important for the ecology of BBD cyanobacteria since these conditions reflect the natural microenvironments of $\mathrm{BBD}$ at night. Microelectrode studies (Richardson et al. 2001) have shown that oxygen is present near the surface of the band and extends to a depth of several hundreds of microns into the band during the period following dusk, resulting in a period every day in which parts of the band are aerobic and dark. During these times, BBD cyanobacteria would carry out the usual metabolic mode of aerobic respiration. After prolonged darkness, however, as sulfide accumulates and aerobic respiration consumes oxygen, the oxygen/sulfide interface moves to the band surface. As a result, for most of the night the entire band is anoxic (Richardson et al. 2001). During this period BBD cyanobacteria switch to an anaerobic metabolic mode. Thus, the metabolism of this cyanobacterium is flexible and adaptive to the dynamic environment of the band.

These results, together with the results of our previous studies of sulfide-resistant oxygenic photosynthesis by BBD Geitlerinema (Richardson and Kuta 2003, Myers et al. 2007), demonstrate that BBD Geitlerinema is physiologically capable of taking advantage of the BBD environment in both light and darkness and is therefore well adapted to this unique and highly fluctuating ecological niche. Both metabolic abilities are important in the microbial ecology of the band. For example, most other (oxygenic) photosynthetic microorganisms, including most cyanobacteria, cannot tolerate sulfide and would thus be excluded from the 
nutrients available in the band, yielding a competitive advantage to Geitlerinema. The ability to use exogenous organic carbon when the band is anaerobic allows BBD Geitlerinema to physiologically take advantage of the organic-rich BBD environment during darkness, and may allow them to avoid death. Stal and Moezelaar (1997) report that cyanobacterial species that could not carry out fermentation of carbon (endogenous or exogenous) died and lysed within 2-3 hours after exposure to dark anoxic conditions. They propose that the capability of fermentation is "essential" for those cyanobacteria that are naturally exposed to conditions of anoxia and darkness, as is the case with BBD cyanobacteria. Although we did measure fermentation byproducts in our experimental cultures, the source of these byproducts could be the sheathassociated bacteria present in the cultures and those results are not presented here. Therefore, we can only suggest that the BBD Geitlerinema sp. is capable of fermenting. However, the prolonged nature of the enhanced survival of BBD Geitlerinema (19 days) suggests that this isolate is capable of growing heterotrophically on the exogenous organic carbon provided. Again, although we did measure positive growth rates via a protein assay during dark incubations, sheath-associated heterotrophic bacteria in the Geitlerinema culture may have contributed to these results and those data are not presented here. It has been calculated that $5-30 \mathrm{mM}$ of exogenous carbon would be required to support anaerobic chemoorganotrophic cyanobacterial growth (Stal and Moezelaar 1997). Since the horizontal migration of BBD over coral provides a continual source of lysing coral tissue as well as continued access to coral mucus, the requirement for a constant supply of organic carbon substrate appears to be fulfilled. The observed enhanced survival of BBD Geitlerinema may be due to an environmentally relevant case of cyanobacterial heterotrophy.

\section{ACKNOWLEDGMENTS}

This research was supported by an EPA MAI Graduate Fellowship to D.R. (F3M10003) with partial support from NIH (NIH/NIGMS SO6GM8205) to L.R. We thank Gene Rosenberg for translating the abstract.

\section{RESUMEN}

La enfermedad de la banda negra que afecta a los corales (BBD, por sus siglas en ingles) está compuesta de una "alfombra" de microbios patógenos dominado por cianobacterias filamentosas que se deslizan horizontalmente. Estas cianobacterias son fundamentales en la etiología de la BBD porque forman la matriz densa de la banda y son el origen de una cianotoxina que contribuye a la patogénesis de la BBD. El ambiente de la BBD es químicamente dinámico, con cambios entre condiciones oxigenadas y anóxicas, y con altas concentraciones de sulfuro. Además, la $\mathrm{BBD}$ es rica en nutrientes y en carbono orgánico debido a la presencia de tejidos de corales que liberan activamente el contenido de las células. Las cianobacterias de la BBD están adaptadas al ambiente de la BBD, en luz y oscuridad. Trabajos anteriores han demostrado que durante el día, las cianobacterias de la BBD pueden hacer fotosíntesis oxigénica sin verse afectadas por la presencia del sulfuro. Comunicamos los resultados de un estudio de laboratorio sobre el matabolismo en la oscuridad de un cultivo de la cianobacteria de la BBD Geitlerinema sp. La supervivencia de esta estirpe, tanto en condiciones oxigenadas como en condiciones anóxicas, fue sustentada por fuentes exógenas de carbono orgánico (azúcares y aminoácidos). El mayor efecto se produjo en condiciones anóxicas. De noche esta cianobacteria está fisiológicamente adaptada al ambiente de la BBD, rico en sustancias orgánicas, mientras que de día está adaptada al ambiente iluminado rico en sulfuro.

Palabras clave: cianobacteria, fermentación, Geitlerinema sp., enfermedad de banda negra, tapetes microbianos.

\section{REFERENCES}

Antonius, A. 1981. The "Band” diseases in coral reefs. Proc. Fourth Int. Coral Reef Symp. Philippines 2: 7-14.

Bruckner, A.W. \& R.J. Bruckner. 1997. The persistence of black band disease in Jamaica: impact on community structure. Proc. 8th Int. Coral Reef Symp., Panama I: 601-606.

Carlton, R.G. \& L.L. Richardson. 1995. Oxygen and sulfide dynamics in a horizontally migrating cyanobacterial mat: black band disease of corals. FEMS Microbiol. Ecol. 18: 155-162.

Castenholz, R.W. 1982. Motility and taxes, p. 413-440. In N.G. Carr \& B.A. Whitton (eds). The Biology of Cyanobacteria. Berkeley, University of California Press. 
Castenholz, R.W., B.B. Jørgensen, E. D’ Amelio \& J. Bauld. 1991. Photosynthetic and behavioral versatility of the cyanobacterium Oscillatoria boryana in a sulfide-rich microbial mat. FEMS Microbiol. Ecol. 86: 43-58.

Castenholz, R.W. \& H. Utkilen. 1984. Physiology of sulfide tolerance in a thermophilic Oscillatoria. Archiv. Microbiol. 138: 299-305.

Coffroth, M. 1990. Mucus sheet formation on poritid corals: an evaluatoin of coral mucus as a nutrient source on coral reefs. Marine Biology 105: 39-49.

Cohen, Y., B.B. Jørgensen, N. P. Revsbech \& R. Poplawski. 1986. Adaptation to hydrogen sulfide of oxygenic and anoxygenic photosynthesis among cyanobacteria. Appl. Env. Microbiol. 51: 398-407.

Ducklow, H.W. \& R. Mitchell. 1979. Bacterial populations and adaptations in the mucus layers on living corals. Limnol. Oceanogr. 24: 715-725.

Garcia-Pichel, F. \& R.W. Castenholz. 1990. Comparative anoxygenic photosynthetic capacity in 7 strains of a thermophilic cyanobacterium. Arch. Microbiol. 153: 344-351.

Garcia-Pichel, F., M. Mechling \& R.W. Castenholz. 1994. Diel migrations of microorganisms within a benthic, hypersaline mat community. Appl. Env. Microbiol. 60: 1500-1511.

Hudson, J. 1981. Growth rates of Montastraea annularis: a record of environmental change in the Key Largo National Marine Sanctuary, Florida. Bull. Mar. Sci. 31: 444-459.

Jørgensen, B.B. 1982. Ecology of the bacteria of the sulphur cycle with special reference to anoxic-oxic interface environments. Phil. Trans. R. Soc. Lond. 298: 543-561.

Jørgensen, B.B. \& N.P. Revsbech. 1983. Colorless sulfur bacteria, Beggiatoa spp. and Thiovulum spp. in $\mathrm{O}_{2}$ and $\mathrm{H}_{2} \mathrm{~S}$ microgradients. Appl. Env. Microbiol. 45: $1261-1270$

Jørgensen, B.B., Y. Cohen \& N.P. Revsbech. 1986. Transition from anoxygenic to oxygenic photosynthesis in a Microcoleus chthonoplastes cyanobacterial mat. Appl. Env. Microbiol. 51: 408-417.

Jørgensen, B.B., N.P. Revsbech T.H. Blackburn \& Y. Cohen. 1979. Diurnal cycle of oxygen and sulfide microgradients and microbial photosynthesis in a cyanobacterial mat sediment. Appl. Env. Microbiol. 38: 46-58.
Kuta, K.G. \& L.L. Richardson. 1996. Abundance and distribution of black band disease of corals in the northern Florida Keys. Coral Reefs. 15: 219-223.

Matthijs, H.C.P. \& H.J. Lubberding. 1988. Dark respiration in cyanobacteria, p. 131-145. In L.J. Rogers \& E.R. Gallon (eds), Biochemistry of the Algae and Cyanobacteria. Clarendon Press, Oxford.

Myers, J.L., R. Sekar \& L.L. Richardson. 2007. Molecular detection and ecological significance of the cyanobacterial genera Geitlerinema and Leptolyngbya in black band disease of corals. Appl. Env. Microbiol. 73: 5173-5182.

Ragoonath, D.N. 2005. Heterotrophic capabilities and the molecular identification of a cyanobacterium found in black band disease of coral reefs. M.S. thesis. Florida International University, Miami.

Richardson, L.L. 1996. Motility patterns of Phormidium corallyticum and Beggiatoa spp. associated with black band disease of corals. Microbial Ecol. 32: 323-335.

Richardson, L.L. \& R.W. Castenholz. 1987a. Diel vertical movements of the cyanobacterium Oscillatoria terebriformis in a sulfide-rich hot spring microbial mat. Appl. Env. Microbiol. 53: 2142-2150.

Richardson, L.L. \& R.W. Castenholz. 1987b. Enhanced survival of the cyanobacterium Oscillatoria terebriformis in darkness under anaerobic conditions. Appl. Env. Microbiol. 53: 2151-2158.

Richardson, L.L., R. Sekar, J. Myers, M. Gantar, E.R. Remily, L. Kaczmarsky, J.D. Voss, G.L. Boyer and P.V. Zimba. 2007. The presence of the cyanobacterial toxin microcystin in black band disease of corals. FEMS Microbiol. Lett. 272: 182-187.

Richardson, L.L. \& K.G. Kuta. 2003. Ecological physiology of the black band disease cyanobacterium Phormidium corallyticum. FEMS Microbiol. Ecol. 43: 287-298.

Richardson, L.L., G.W. Smith, Ritchie, K.B. \& R.G. Carlton. 2001. Integrating microbiological, microsensor, physiologic and molecular techniques in the study of coral disease pathogenesis. Hydrobiologia 460: 71-89.

Rützler, K. and D.L. Santavy. 1983. The black band disease of Atlantic reef corals. I. Description of the cyanophyte pathogen. P.S.Z.N.I: Mar. Ecol. 4: 301-319.

Rützler, K., D.L. Santavy \& A. Antonius. 1983. The black band disease of Atlantic reef corals. III. Distribution, ecology and development. PSZNI: Mar. Ecol. 4: 329-358. 
Stal, L.J. 1995. Physiological ecology of cyanobacteria in microbial mats and other communities. New Phytol. 131: 1-32.

Stal, L.J. \& R. Moezelaar. 1997. Fermentation in cyanobacteria. FEMS Microbiol. Rev. 21: 179-211.
Sutherland, K.P., J.W. Porter \& C. Torres. 2004. Disease and immunity in Caribbean and Indo-Pacific zooxanthellate corals. Mar. Ecol. Prog. Ser. 266: 273-302.

Viehman, T.S. \& L.L. Richardson. 2002. Motility patterns of Beggiatoa and Phormidium corallyticum in black band disease. Proc. Ninth Int. Coral Reef Symp., Indonesia. 2: 1251-1256. 